\title{
Implications of till-provenance studies for glaciological reconstructions of the paleoglaciers of Wildhorse Canyon, Idaho, U.S.A.
}

\author{
KeITH A. BRUgGer \\ Deparlment of Geology, University of Minnesota-Morris, Morris, M.N 56267, U.S.A.
}

\begin{abstract}
Detailed till-provenance studies of moraine complexes in the Wildhorse Canyon area, Idaho, U.S.A., allow inferences to be made regarding the flow paths and dynamics of Wildhorse and Fall Creek Glaciers, the two principal tributaries constituting a late-Pleistocene compound glacier. In particular, the distribution of statistically defined pebble and mineral assemblages within moraine complexes suggests that Wildhorse Glacier contributed a substantially greater volume of ice to the trunk glacier than did Fall Creek Glacier.

An initial group of glaciological reconstructions yields estimates for the equilibrium-line altitude (ELA) of the compound glacier that are consistent with those independently arrived at using other methods of ELA determination. Ice-flux calculations imply, however, that for each reconstruction the relative contributions of ice from Wildhorse and Fall Creek Glaciers were about equal, which is inconsistent with the inferences drawn from the till-provenance data. An alternative reconstruction incorporated possible orographic effects on accumulation and ablation by using different ELAs for the two tributary glaciers. Calculations for this reconstruction suggest that the ice flux of Wildhorse Glacier was about twice that of Fall Creek Glacier. This reconstruction is more consistent with the till-provenance data, and furthermore suggests that such data might be invaluable in choosing between seemingly equally viable glaciological reconstructions of paleoglaciers.
\end{abstract}

\section{INTRODUCTION}

The reconstruction of former valley glaciers has become a common method for estimating paleo-snow-line elevations or equilibrium-line altitudes (ELAs), and thus for inferring Quaternary paleoclimate for mountainous regions throughout the world (Porter, 1975; 1977; Pierce, 1979; Meierding, 1982; Leonard, 1984; Hawkins, 1985; Murray and Locke, 1989; Torsnes and others, 1993). In brief, an estimate of the ELA is obtained by determining that altitude which yields some specified ratio of the reconstructed glacier's accumulation area to its total area. This ratio is referred to as the accumulation-area ratio (AAR). By analogy with modern glaciers in equilibrium with existing climates, the AAR is assumed to be between 0.50 and 0.80 depending on the glacier's area-altitude distribution (Meier and Post, 1962; Pierce, 1979; Porter, 1981; Leonard, 1984). In recent comparisons of methodologies, Meierding (1982), Hawkins (1985) and Torsnes and others (1993) have concluded that the AAR method, because it has a more sound physical basis, results in the most accurate determination of paleo-ELAs. The paleoclimatic significance of variations in ELAs has generally been interpreted in terms of temperature change by applying a lapse rate to calculated ELA depressions, largely ignoring the effects of changes in snow accumulation and radiation balances (Seltzer, 1994).
Reconstructions of the mass balances and dynamics of paleoglaciers are alternatives to the "static" determination of ELAs using the AAR method. Paleo-mass balances can be approximated given some knowledge of mass-flux variations over the length of the glacier and the assumption of steady-state mass continuity. The paleomass-balance curve thus determined also defines the ELA. Such glaciological reconstructions have the potential to yield more useful climatic information because mass-balance gradients can be related to specific climatic regimes (Kuhn, 1981, 1984). This approach is problematic, however, inasmuch as mass-flux calculations are strongly dependent upon basal sliding velocities. Thus, various ad hoc assumptions must be made regarding the magnitude of sliding at the base of the paleoglacier (e.g. Murray and Locke, 1989).

A different approach to glaciological reconstructions is to use mass-balance curves of modern glaciers that are analogous in size and climatic setting to the paleoglaciers. Using the chosen mass-balance curve with the areaaltitude distribution of a paleoglacier, the ELA can be determined by varying the altitude of the equilibrium line until net accumulation above equals net ablation below. This technique has been used to directly reconstruct the ELA (Porter and others, 1983) and as a means to independently evaluate ELAs determined by other methods (Pierce, 1979). For the former, the assumption 
of equivalence of climatic setting of the paleoglacier and modern analog presents a potential difficulty: the ELA of the paleoglacier is of interest precisely for its paleoclimatic implications, but its determination is based on some presumption of climatic conditions. Thus it is imperative to consider additional sources of information that might be used to verify the reliability of the reconstruction. This paper demonstrates how the information provided by detailed till-provenance studies can be used to discriminate between equally viable glaciological reconstructions of paleoglaciers.

\section{TILL PROVENANGE AND GLACIER DYNAMICS}

The drainage of Wildhorse Canyon, Idaho, U.S.A., has been modified by at least two and possibly three episodes of glaciation. The youngest, a late-Pleistocene event informally known as the "Wildhorse Canyon advance", is represented by a series of terminal moraine complexes that document four distinct phases of glacier activity. The glacial history of the Wildhorse Canyon area has been discussed in detail elsewhere (Brugger and others, 1983), so in the interest of brevity it is summarized in Figure 1.
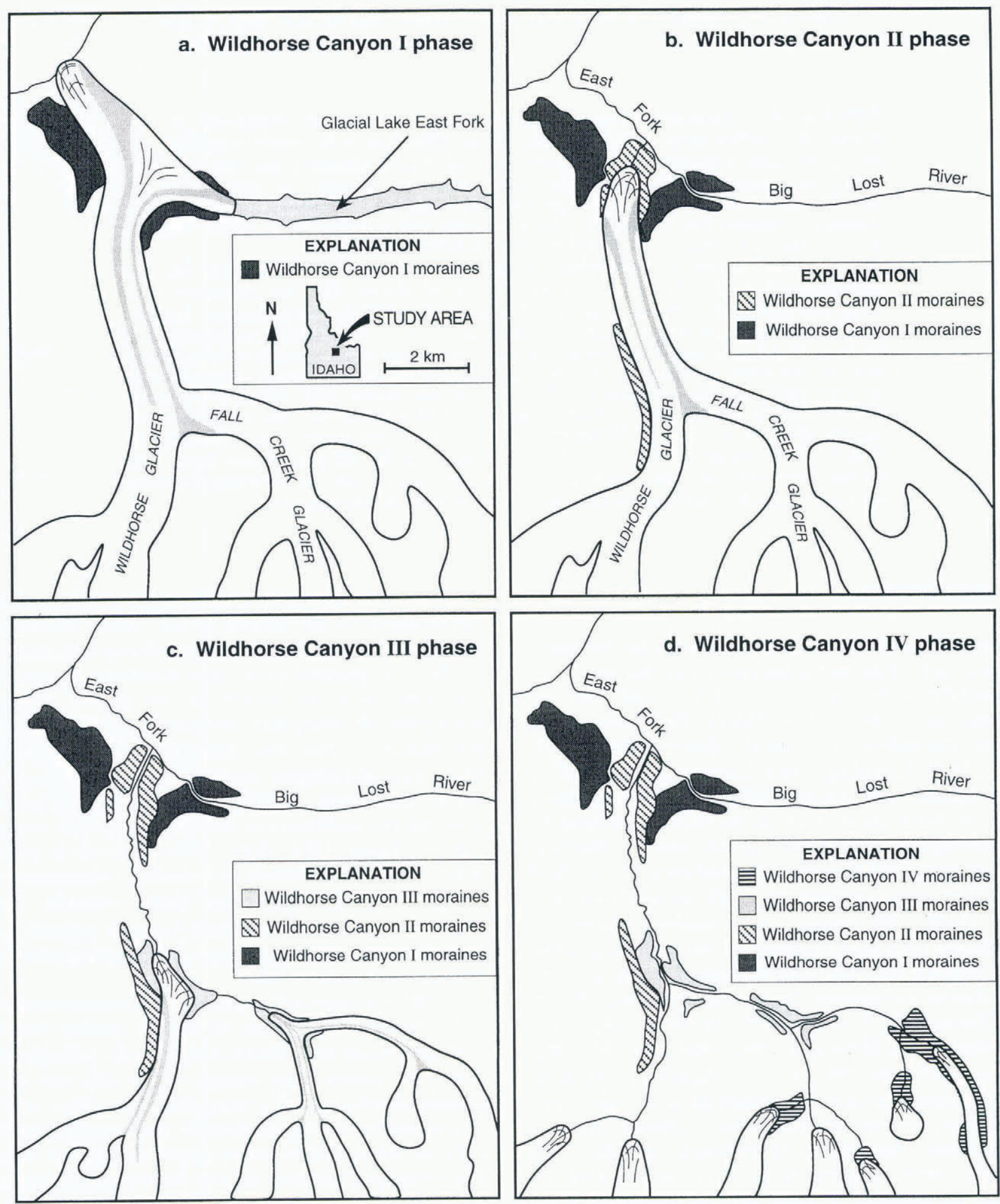

Fig. 1. Schematic illustration of the glacial history of Wildhorse Canyon for the four phases of the late-Pleistocene "Wildhorse Canyon Glaciation". 
Because the two major catchment areas of Wildhorse Canyon are underlain by distinctly different bedrock types (Dover, 1981), pebble and heavy mineral compositions of the tills clearly indicate the source areas from which they were derived (Brugger and others, 1983). Tills composed of metamorphic clasts and heavy-mineral assemblages enriched in clinopyroxenes mostly diopside) are derived from Precambrian gneisses, schists and quartzites - rock types exposed only in the headwaters of Wildhorse Creek proper. In contrast, tills originating from the Fall Creek drainage are characterized by relatively high percentages of granitic clasts and the absence of metamorphic lithologies.

By using the statistical techniques of factor and cluster analysis (Davis, 1986), several till-compositional groups were identified on the basis of their unique pebble lithologies and heavy-mineral assemblages. The statistically defined groups were thus interpreted Brugger and others, 1983) as being either (a) source suites, composed predominantly of indicator lithologies and minerals; (b) dilute source suites, composed predominantly of pebble lithologies and mineral assemblages not indicative of a particular catchment area, but having a small percentage of an indicator lithology present; or (c) mixed suites, having indicators of both catchment areas in varying amounts. Average compositions of these different suites are shown in Table 1 . Table 1 also reveals that the dilutants in the dilute source suites are sedimentary clasts in the pebble fraction, and calcite in the heavy mineral fraction. These components were incorporated into the source tills as the glaciers eroded Paleozoic clastic and carbonate sequences that occur in the lower reaches of the trunk valley.

Terminus geometries of the glaciers in Wildhorse Canyon were reconstructed by Brugger and others (1983) for all phases of glaciation using the provenance data. A condensed interpretation for the Wildhorse Canyon I and II phases is presented in Figure 2. The significance of these reconstructions is that the distribution of indicator pebbles and minerals in moraine complexes reflects the relative magnitudes of the individual glaciers constituting the compound glacier. This is seen in Figure 2a where the sharp break in till compositions of the Wildhorse Canyon II moraine complex is interpreted to define the position of the medial moraine separating Wildhorse and Fall Creek
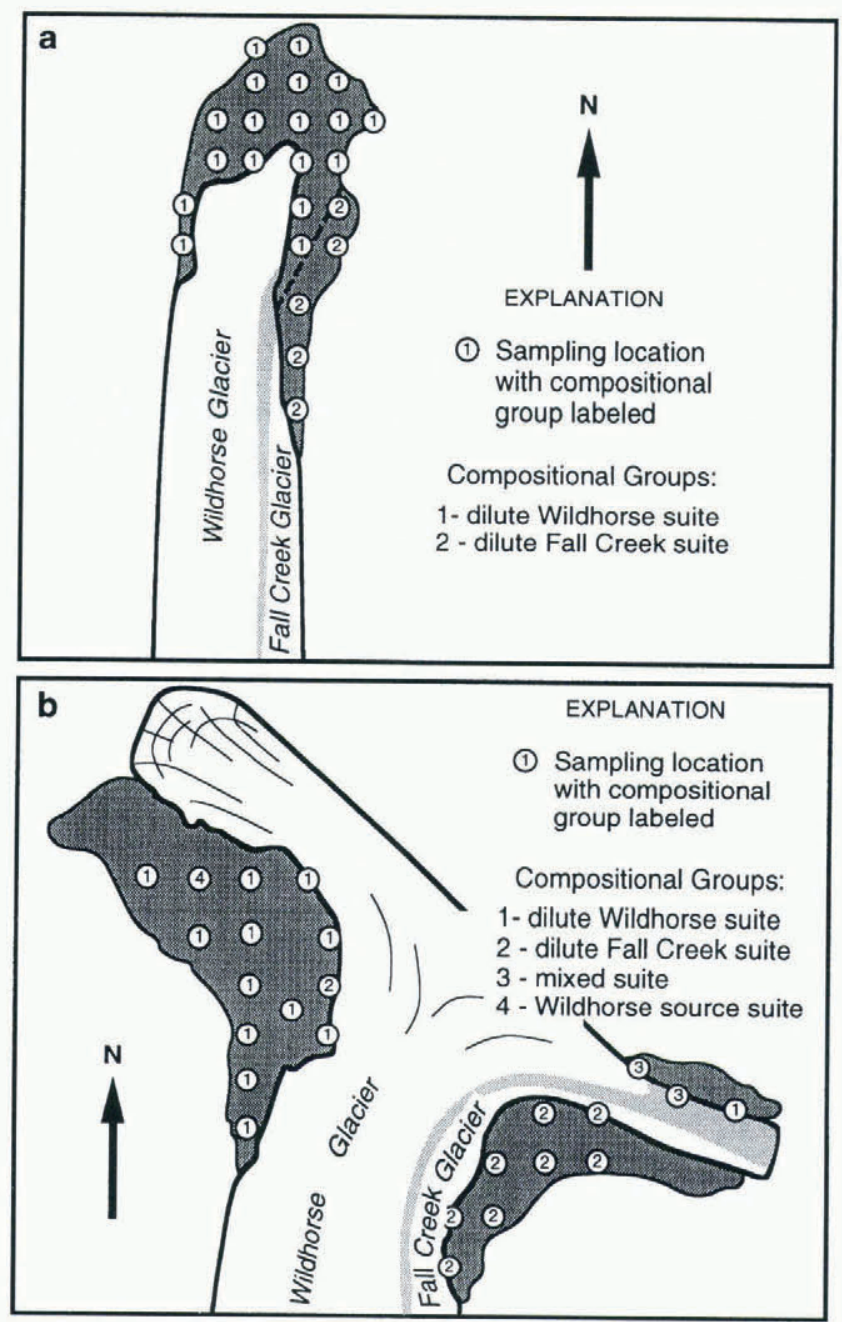

Fig. 2. Terminus geometries for the (a) Wildhorse Canyon II, and (b) Wildhorse Canyon I phases of glaciation, reconstructed on the basis of till provenance.

Glaciers. Because the compositional break occurs along the east-lateral extension of the moraine complex, Fall Creek Glacier is assumed to have been restricted to a similarly lateral position within the compound glacier. On modern, non-surging, compound glaciers it can be observed that the widths of individual ice streams as delineated by medial moraines) are roughly proportional

Table 1. Average compositions (\%) of the statistically defined till-provenance groups

\begin{tabular}{|c|c|c|c|c|c|c|c|}
\hline \multirow[t]{2}{*}{ Suite } & \multicolumn{3}{|c|}{ Pebble lithologies } & \multicolumn{4}{|c|}{ Heavy minerals } \\
\hline & Metamorphics & Granitics & Sedimentary & $C P X^{*}$ & Sphene & Calcile & Others \\
\hline \multicolumn{8}{|l|}{ Wildhorse } \\
\hline Source & 54 & 10 & 36 & 28 & 1 & 0 & 71 \\
\hline Dilute & 12 & 2 & 86 & 18 & 1 & 11 & 70 \\
\hline \multicolumn{8}{|l|}{ Fall Creek } \\
\hline Source & 0 & 100 & 0 & 0 & 6 & 0 & 94 \\
\hline Dilute & 0 & 18 & 82 & 0 & 3 & 29 & 68 \\
\hline Mixed & 2 & 4 & 94 & 6 & 6 & 8 & 80 \\
\hline
\end{tabular}

* Clinopyroxenes (mostly diopside). 
to the size of the catchment areas from which they flow. This is a logical consequence of differences in the ice flux contributed by each catchment area. Therefore it is concluded that the Wildhorse catchment area contributed a much greater volume of ice to the compound glacier than did the Fall Creek catchment area.

The position of the medial moraine during the Wildhorse Canyon I phase is more difficult to ascertain because of the non-continuous nature of the associated moraine complex. The position shown in Figure $2 \mathrm{~b}$ is based on the following reasoning. First, the till composition of the small moraine segment northeast of the terminus indicates either a Wildhorse provenance or a mixed provenance. Although few in number, the presence of metamorphic lithologies in all till samples requires that the till was, at least in part, deposited by Wildhorse Glacier. The mixed-source samples are therefore interpreted as representing the composition of the medial moraine. Secondly, shorelines of Glacial Lake East Fork (Fig. la) are delineated by concentrations of ice-rafted boulders of Wildhorse provenance (Brugger and others, 1983). Thus a source for these boulders must be present at the calving margin of the compound glacier. The inferred position of the medial moraine again has the implication that the Wildhorse catchment area provided a substantially larger volume of ice to the compound glacier than did the Fall Creek catchment area.

That the relative contribution of Wildhorse Glacier to the compound glacier was significantly greater than that of Fall Creek Glacier is consistent with the glacial history of the area. Of particular note is the waning contribution of Fall Creek (Fig. lc) ice during the course of the Wildhorse Canyon advance as described by Brugger and others (1983). Consequently, any reconstructions of these paleoglaciers should also be in accord with the tillprovenance studies.

\section{RECONSTRUCTION OF THE PALEOGLACIERS}

Ice surface contours of the paleoglaciers were reconstructed for the Wildhorse Canyon I phase of glaciation following the procedure given by Pierce (1979) and Porter (1981). The areal extent of the compound glacier and its tributaries was determined using the geometry of moraine segments, the upper limits of erratic boulders and the upper limits of glacial erosion. The elevations at glacier margins were used to establish initial surface contours by assuming convergent and divergent flow in accumulation and ablation areas, respectively, and with due consideration of the constraints of bedrock topography on local ice flow. Longitudinal profiles obtained from the reconstructed ice surfaces provided estimates of ice thicknesses and surface slopes, which were then used to calculate basal shear stresses along both the compound glacier and its constituent ice streams. The shear stress $\tau$ is given by

$$
\tau=f \rho g h \sin \alpha
$$

where $f$ is a "shape factor" to account for drag from the valley sides, $\rho$ is the density of ice, $g$ is the acceleration due to gravity, $h$ is the ice thickness, and $\alpha$ is the surface slope.
Surface slopes were averaged over a distance one order of magnitude larger than the local ice thickness to account for longitudinal stress gradients (Paterson, 1981, p. 101). Ice surface contours were then adjusted so that the shear stresses computed at over 30 locations fell within, or were close to, the commonly accepted range of $50-150 \mathrm{kPa}$ (Paterson, 1981, p. 86). The reconstructed compound glacier and profiles of Wildhorse and Fall Creek Glaciers are shown in Figures 3 and 4.

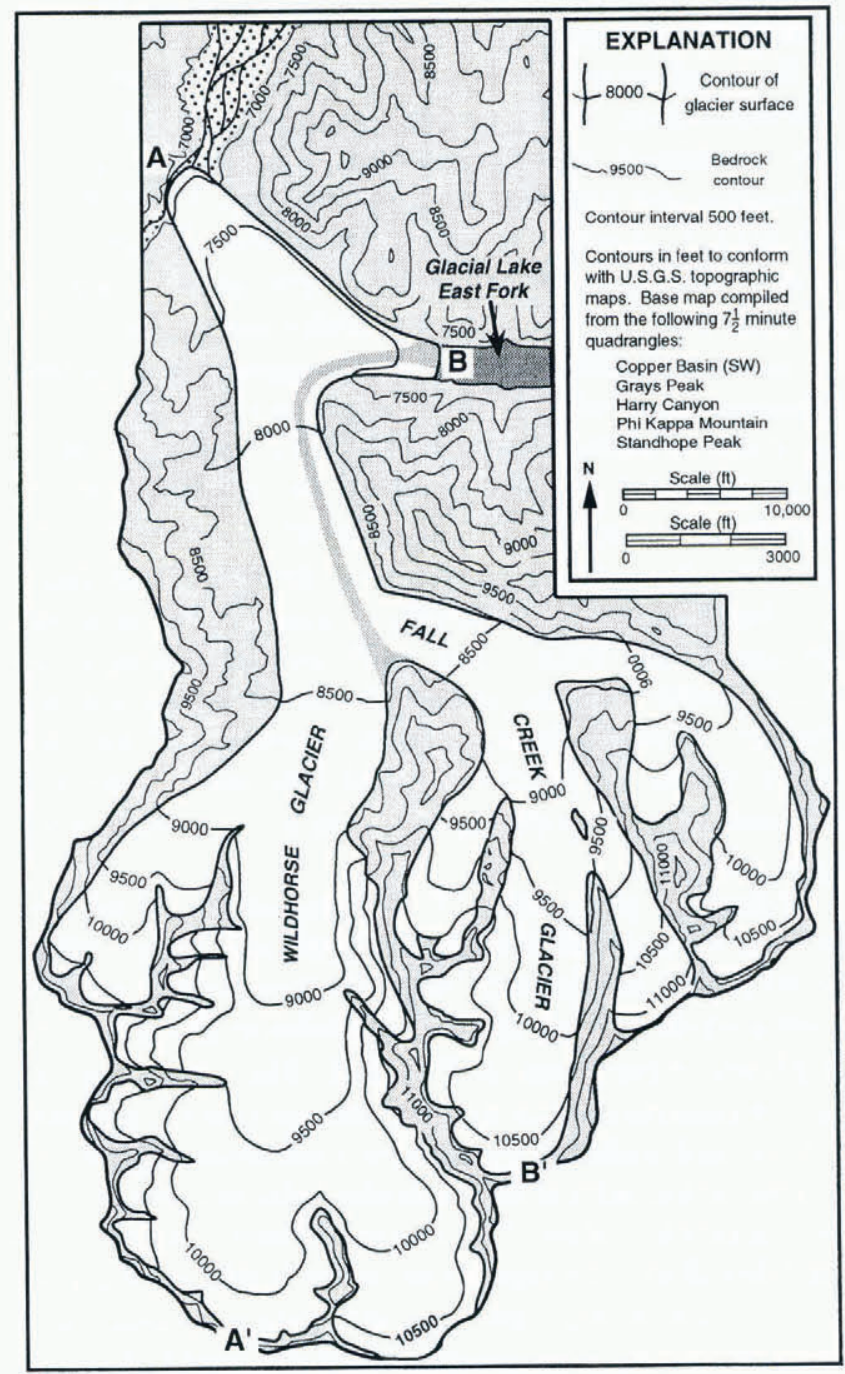

Fig. 3. Reconstruction of the compound glacier of Wildhorse Canyon for the Wildhorse Canyon I phase of glaciation. Longitudinal profiles $A-A^{\prime}$ and $B-B^{\prime}$ are shown in Figure 4.

Three simple, specific net balance curves for the compound glacier were constructed using the massbalance characteristics of modern glaciers found in continental-type climatic regimes Grosval'd and Kotlyakov, 1969; Meier and others, 1971; Wendler and others, 1975; Young and Stanley, 1976a, b; Kuhn, 1984). For such glaciers, maximum accumulations are typically $1-$ $2 \mathrm{~m}$ w.e., while ablation gradients range from about 0.005 to $0.01 \mathrm{~m}$ w.e. $\mathrm{m}^{-1}$. Therefore, an "average" curve (Fig. 5; Table 2A) was created using the intermediate values of $1.5 \mathrm{~m}$ w.e. for maximum accumulation and $0.0075 \mathrm{~m}$ 

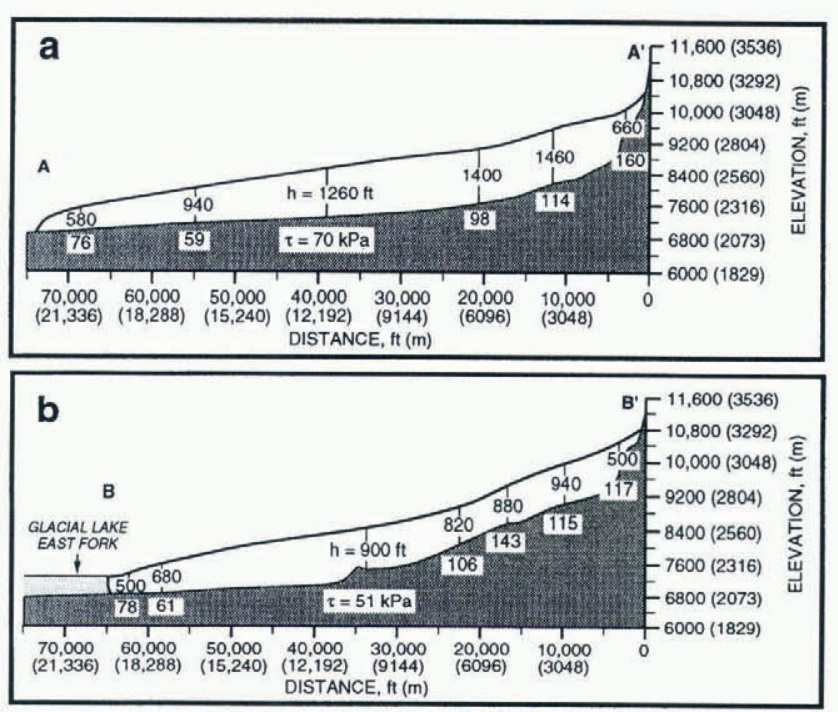

Fig. 4. Longitudinal profiles of the Wildhorse (profile $\left.A-A^{\prime}\right)$ and Fall Creek $\left(B-B^{\prime}\right)$ glaciers. Ice thickness $h$ and calculated basal shear stress $\tau$ values are shown for various localions.
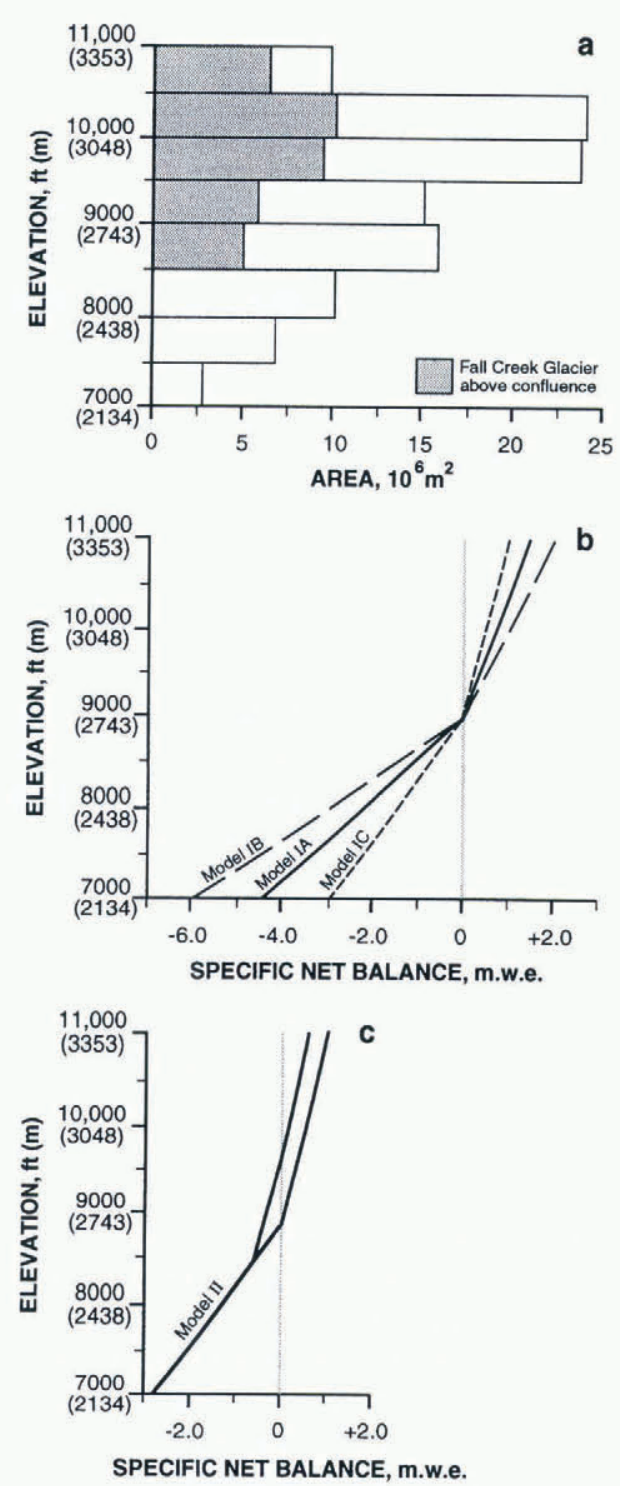

Fig. 5. (a) Area-altitude distribution for the compound glacier of Wildhorse Canyon; and the specific net balance curves used in the model I (b) and model II (c) reconstructions. w.e. $\mathrm{m}^{-1}$ for the ablation gradient. It is also commonly observed that higher accumulations and ablation gradients tend to occur under more moderate continental climates. Conversely, lower accumulations and ablation gradients tend to occur together on glaciers of colder continental climates. These conditions are represented by curves (Fig. 5; Table 2B and $\mathrm{C}$ ) having maximum accumulations and ablation rates of $2.0 \mathrm{mw}$.e. and $0.01 \mathrm{~m}$ w.e. $\mathrm{m}^{-1}$, and $1.0 \mathrm{mw}$ we. and $0.005 \mathrm{~m}$ w.e. $\mathrm{m}^{\prime}$, respectively. The latter is considered to be more representative of prevailing conditions in the Wildhorse Canyon area during the late Pleistocene based on recent studies that suggest colder and drier climates than presently exist in the Rocky Mountains (Porter and others, 1983; Leonard, 1989; Locke, 1990). For the idealized curves it was assumed that both net ablation and net accumulation varied linearly with elevation. Finally, no attempt was made to account for calving along the eastern margin of the terminus (Fig. 3), as the mass loss here is thought to have been insignificant.

The specific net balance curves were used in conjunction with the glacier's area-altitude distribution (Fig. 5) to estimate the ELA associated with each massbalance curve. These ELA reconstructions are henceforth referred to collectively as model I and individually as models IA-C, corresponding to the mass balances given in Table 2. The elevations of the equilibrium lines were located by imposing a condition of steady state, that is

$$
\sum_{i=1}^{k} \bar{b}_{\mathrm{n}} \mathrm{S}_{i} \approx 0
$$

where $\bar{b}_{\mathrm{n}_{i}}$ is the mean specific net balance over the area $S_{i}$ for the $i$ th elevation interval of the glacier, and $k$ is the number of elevation intervals. The ELAs determined for models IA-C: (Table 2) are remarkably similar, all being about $8960 \mathrm{ft}^{\text {" }}(2730 \mathrm{~m})$. It must be noted here that because of the considerable latitude inherent in generating mass-balance curves for the paleoglacier, there can be no "unique" ELA determined. The fortuitous agreement of these results is an artifact of the specific combinations of accumulation and ablation gradients used in the models. Other models using different combinations result in notably different ELAs (Brugger, unpublished data). Thus, as alluded to earlier, it was necessary to independently access the viability of the reconstructions.

Two methods were used to assess the glaciological reconstructions. The first involved the calculation of the AAR, which was then compared with those associated with the ELAs estimated above. For valley glaciers, an AAR of $0.65 \pm 0.5$ is usually taken as being indicative of steady state Andrews and Miller, 1972; Porter, 1981; Meierding, 1982; Leonard, 1984). Outside this range, larger values are representative of glaciers fed by upland ice fields, whereas smaller values are more typical of piedmont-type glaciers (Leonard, 1984). For the glacier system of Wildhorse Canyon an AAR of 0.65 corresponds to an ELA of $9100 \mathrm{ft}(2774 \mathrm{~m})$, slightly greater than that

\footnotetext{
* English units are retained for elevations in order to conform with U.S. topographical maps.
} 
Table 2. Results of model I reconstructions (all mass-balance and flux quantities are water-equivalent values)

\begin{tabular}{|c|c|c|c|c|c|c|}
\hline \multirow[t]{3}{*}{$i$} & \multirow[t]{2}{*}{$\begin{array}{c}\text { Elevation } \\
\text { interval }\end{array}$} & \multirow[t]{2}{*}{ Area } & \multirow[t]{2}{*}{$\begin{array}{c}\text { Specific net } \\
\text { balance }\end{array}$} & \multirow[t]{2}{*}{$\begin{array}{c}\text { Net } \\
\text { balance }\end{array}$} & \multirow[t]{2}{*}{$\begin{array}{l}\text { Cumulative } \\
\text { net balance }\end{array}$} & $\begin{array}{l}\text { Ice flux through } \\
\text { lower boundary }\end{array}$ \\
\hline & & & & & & Wildhorse $\quad$ Fall Creek \\
\hline & $\mathrm{ft}$ & $10^{6} \mathrm{~m}^{2}$ & $\mathrm{~m}$ & $10^{6} \mathrm{~m}^{3}$ & $10^{6} \mathrm{~m}^{3}$ & $10^{6} \mathrm{~m}^{3} \mathrm{a}^{-1}$ \\
\hline
\end{tabular}

A. Maximum accumulation $=1.5 \mathrm{mw}$.e.

Ablation gradient $=0.0075 \mathrm{~m}$ w.e. $\mathrm{m}^{-1}$

$\mathrm{ELA}=8960 \mathrm{ft}(2730 \mathrm{~m})$

1
2
3
4
5
6
7
8

$\begin{array}{cr}11000-10500 & 9.92 \\ 10500-10000 & 24.02 \\ 10000-9500 & 23.78 \\ 9500-9000 & 14.99 \\ 9000-8500 & 15.80 \\ 8500-8000 & 10.10 \\ 8000-7500 & 6.66 \\ 7500-7000 & 2.73\end{array}$

$\begin{array}{rr}1.31 & 13.1 \\ 0.95 & 22.9 \\ 0.58 & 13.8 \\ 0.21 & 3.2 \\ -0.48 & -7.6 \\ -1.62 & -16.4 \\ -2.77 & -18.4 \\ -3.91 & -10.7\end{array}$

13.1

35.8

49.7

52.8

45.2

28.8

10.4

$-0.3^{\dagger}$

B. Maximum accumulation $=2.0 \mathrm{~m}$ w.e.

Ablation gradient $=0.01 \mathrm{~m}^{\text {w.e. }} \mathrm{m}^{-1}$

$\mathrm{ELA}=8960 \mathrm{ft}(2730 \mathrm{~m})$

$$
2
$$$$
3
$$$$
\begin{aligned}
& 4 \\
& 5
\end{aligned}
$$

$\begin{array}{cr}11000-10500 & 9.92 \\ 10500-10000 & 24.02 \\ 10000-9500 & 23.78 \\ 9500-9000 & 14.99 \\ 9000-8500 & 15.80 \\ 8500-8000 & 10.10 \\ 8000-7500 & 6.66 \\ 7500-7000 & 2.73\end{array}$

1.75

1.26

0.77

0.28

$-0.64$

$-2.16$

$-3.68$

$-5.21$

17.4
30.4
18.8
4.3
-10.2
-21.9
-24.6
-14.2

17.4

47.8

66.2

70.5

60.3

38.4

13.9

$-0.4^{\dagger}$

6.1

23.7

34.8

37.4

30.3

11.3

24.0

31.4

33.1

30.0

38.4

13.9

$(-0.4)$

C. Maximum accumulation $=1.0 \mathrm{~m}$ w.e.

Ablation gradient $=0.005 \mathrm{~m}$ w.e. $\mathrm{m}^{-1}$

$\mathrm{ELA}=8960 \mathrm{ft}(2730 \mathrm{~m})$

1
2
3
4
5
6
7
8

$\begin{array}{cr}11000-10500 & 9.92 \\ 10500-10000 & 24.02 \\ 10000-9500 & 23.78 \\ 9500-9000 & 14.99 \\ 9000-8500 & 15.80 \\ 8500-8000 & 10.10 \\ 8000-7500 & 6.66 \\ 7500-7000 & 2.73\end{array}$

0.88

8.70

8.70

3.1

5.7

0.63

15.2

0.38

9.21

0.14
-0.32

2.1
-5.1

$-1.08$

$-10.9$

$-12.3$

$-1.84$

$-7.1$
23.9

33.1

35.2

30.2

19.2

11.8

17.3

18.6

15.1

15.8

16.6

15.0

19.2

6.9

$-0.2^{\dagger}$
8.5

18.1

23.6

24.8

22.4

28.8

$(-0.3)$

\footnotetext{
*Values in bold-face type represent the ice flux immediately above the confluence of Wildhorse and Fall Creek Glaciers.

$\dagger$ Values represent a net imbalance of less than $1 \%$.
}

of $8960 \mathrm{ft}(2730 \mathrm{~m})$ obtained by the mass-balance method. The latter elevation yields an AAR of 0.68 , well within the acceptable range.

A second method to determine the ELA is to calculate the toe-to-headwall altitude ratio (THAR). Based on empirical studies of modern glaciers, different THAR values ranging from 0.35 to 0.50 (the median glacier elevation) have been used by different investigators (Porter, 1981; Meierding, 1982; Hawkins, 1985; Murray and Locke, 1989; Torsnes and others, 1993). This wide range of values reflects differences in the interpretation of the term "headwall", the inability to accurately define its elevation, and variations in glacier morphology (Hawkins, 1985). These difficulties notwithstanding, a THAR value of 0.50 has been suggested for glaciers having a normal area-altitude distribution (Porter, 1981; Leonard, 1984). For the reconstructed compound glacier, a THAR value of 0.50 renders an ELA of $9000 \mathrm{ft}(2743 \mathrm{~m})$ which is in excellent agreement with those determined by the AAR and mass-balance methods.

The AAR and THAR methods would thus appear to confirm the validity of the glaciological reconstructions of 
the paleoglaciers of Wildhorse Canyon. However, given the till-provenance data and their implications, a more rigorous test of viability is to compute the magnitude of the ice flux contributed by each glacier to the compound glacier. Steady-state mass continuity requires that the ice flux $Q$ through any cross-section $j$ must equal the mass balance integrated over that part of the glacier above it. $Q_{j}$ is thus the cumulative mass balance at $j$,

$$
Q_{j} \approx \sum_{i=1}^{j} \bar{b}_{\mathrm{n}_{i}} S_{i} .
$$

Equation (3) was used to calculate the mass flux at successive cross-sections along the lengths of the tributary and compound glaciers for each reconstruction (Table 2 ). Since the cross-sections at the $8500 \mathrm{ft}$ contour lie immediately above the confluence, the mass fluxes here provide estimates of the relative contribution of Wildhorse and Fall Creek Glaciers to the compound glacier. Table 2 reveals that for models IA-C the ice flux entering the trunk valley from Fall Creek is about equal to that from the Wildhorse catchment area. These results are inconsistent with the conclusions drawn from the tillprovenance studies, and therefore problematic.

By using one specific net balance curve for the entire glacier system, model I reconstructions implicitly suppose that the altitudinal dependencies of factors affecting mass balance (such as temperature and precipitation) were the same for the Wildhorse and Fall Creek valleys. Considering the ruggedness of the topography, local variability of these factors would be expected due to orographic effects on precipitation, differences in local energy balances, and so forth. This variability would be indicated if gradients in late-Pleistocene snow lines existed in the study area.

An analysis of cirque-floor elevations was performed to examine this possibility. The trend in the elevations of the lowest cirque floors is thought to approximate the paleosnow line or ELA (Porter, 1964; Andrews and Miller, 1972; Locke, 1990). In Wildhorse Canyon this trend suggests a steep, eastward rise of the paleo-snow line of roughly $30 \mathrm{~m}$ per $\mathrm{km}$. Such steep gradients are not unprecedented in areas of high relief. Porter $(1975,1977)$ reported gradients in late-Pleistocene snow lines up to $23 \mathrm{~m}$ per $\mathrm{km}$ in the Southern Alps of New Zealand, and $25 \mathrm{~m}$ per $\mathrm{km}$ in the Cascade Range of North America. Leonard (1984) reported gradients of 20-24 m per $\mathrm{km}$ for parts of the San Juan Mountains in southwestern Colorado. Given that these are regional gradients, it would not be surprising for local gradients to be steeper within an individual drainage basin.

The significance of snow lines approximated by cirque-floor elevations with respect to time are equivocal, the cirques being erosional forms modified by successive glacial events (Porter and others, 1983; Hawkins, 1985; Locke, 1990). However, a close parallelism of snow-line and ELA gradients of different ages has been documented by several workers (Andrews and Miller, 1972; Porter, 1975, 1977; Zwick, 1980; Leonard, 1984; Locke, 1990), indicating that the climatic factors responsible for regional gradients were relatively constant through time. There being no evidence to the contrary, this was assumed to be the case for the Wildhorse Canyon area.
Thus, a second glaciological reconstruction of the paleoglaciers of Wildhorse Canyon incorporated an ELA gradient equal to that exhibited by the lowest cirque-floor elevations. The specific mass-balance curve for this reconstruction is shown in Figure 5. For reasons discussed previously, the maximum accumulation in the Wildhorse catchment area was chosen as $1.0 \mathrm{~m}$ w.e., and the ablation gradient below the confluence of the two ice streams (for simplicity taken as $8500 \mathrm{ft}$ ) was specified to be 0.005 $\mathrm{m}$ w.e. $\mathrm{m}^{-1}$. It was assumed that accompanying the rise in ELA was a concomitant decrease in accumulation, as observed in modern glaciated regions (Meier and others, 1971; Porter, 1977). Accumulation values for the Fall Creek system were therefore somewhat arbitrarily determined using an accumulation gradient equivalent to that in the Wildhorse catchment. The ablation gradient for Fall Creek Glacier above the confluence was simply defined as that of the line connecting its ELA with the value of ablation at the confluence elevation (Fig. 6).

The results of the second reconstruction are shown in Table 3. The ELAs associated with this model are at $8845 \mathrm{ft}(2696 \mathrm{~m})$ for Wildhorse Glacier and at $9295 \mathrm{ft}$ $(2833 \mathrm{~m})$ for Fall Creek Glacier. These elevations correspond to an AAR of 0.67 for the compound glacier, essentially no different than that determined for models IA-C. The notable difference between the two models lies, however, in their estimation of the relative contribution of the two catchment areas. Above their confluence, model II yields an ice flux of $18.0 \times 10^{6} \mathrm{~m}^{3}$ w.e. $\mathrm{a}^{-1}$ from Wildhorse Glacier and $8.86 \times 10^{6} \mathrm{~m}^{3}$ w.e. ${ }^{-1}$ from Fall Creek Glacier. Thus model II represents a significant improvement over the model I reconstructions in being not only glaciologically sound but also supported by the till-provenance data.

It is worth examining one additional aspect of model II. Steady-state mass continuity requires that

$$
Q=S \bar{u}
$$

where $Q$ is the ice flux given by Equation (3) at some cross-section having an area $S$ and mean ice velocity $\bar{u}$. The mean ice velocity is the sum of the mean ice velocity due to internal deformation $\bar{u}_{\mathrm{d}}$ and the mean sliding velocity $\bar{u}_{\mathrm{b}} \cdot \bar{u}_{\mathrm{d}}$ is given by

$$
\bar{u}_{\mathrm{d}}=f^{*} \frac{2 A \tau^{n} h}{n+1}
$$

where $A$ and $n$ are the flow-law parameters for ice, and $f^{*}$ is a flux-shape factor (Nye, 1965). Parameter $n$ is taken as 3 so that parameter $A$ for $0^{\circ} \mathrm{C}$ is $5.3 \times 10^{-15} \mathrm{~s}^{-1} \mathrm{kPa}^{-3}$ (Paterson, 1981, p. 39). From Equation (5) the mean deformational velocities for Wildhorse and Fall Creek Glaciers are on the order of 7 and $4 \mathrm{~m} \mathrm{a}^{-1}$, respectively. Using the cross-sectional areas $\left(4.7 \times 10^{5}\right.$ and $2.1 \times 10^{5}$ $\mathrm{m}^{2}$ ) and the ice fluxes at the $8500 \mathrm{ft}$ elevation contour, Equation (4) renders mean velocities of $38 \mathrm{ma}^{-1}$ for Wildhorse Glacier and $42 \mathrm{~m} \mathrm{a}^{-1}$ for Fall Creek Glacier. This means that basal sliding accounts for $80-90 \%$ of ice motion at these cross-sections.

The high rates of basal sliding given by model II are rather insensitive to potential errors in the estimates of 
Table 3. Results of model II reconstruction (all mass-balance and flux quantities are water-equivalent values)

\begin{tabular}{|c|c|c|c|c|c|c|}
\hline$i$ & \multirow[t]{2}{*}{$\begin{array}{l}\text { Elevation } \\
\text { interval }\end{array}$} & Area & $\begin{array}{c}\text { Specific net } \\
\text { balance }\end{array}$ & \multirow[t]{2}{*}{$\begin{array}{c}\text { Net } \\
\text { balance }\end{array}$} & \multirow[t]{2}{*}{$\begin{array}{l}\text { Cumulative } \\
\text { net balance }\end{array}$} & $\begin{array}{l}\text { Ice flux through } \\
\text { lower boundary }\end{array}$ \\
\hline & & Fall Creek & Wildhorse $\quad$ Fall Creek & & & Wildhorse Fall Creek \\
\hline & $\mathrm{ft}$ & $10^{6} \mathrm{~m}^{2}$ & $\mathrm{~m}$ & $10^{6} \mathrm{~m}^{3}$ & $10^{6} \mathrm{~m}^{3}$ & $10^{6} \mathrm{~m}^{3} \mathrm{a}^{-1}$ \\
\hline
\end{tabular}

Maximum accumulation $=1.0 \mathrm{~m}$ w.e. in Wildhorse catchment area

Ablation gradient $=0.005 \mathrm{~m}$ w.e. $\mathrm{m}^{-1}$

ELAs $=8845 \mathrm{ft}(2696 \mathrm{~m})$ Wildhorse; $9295 \mathrm{ft}(2833 \mathrm{~m})$ Fall Creek

$\begin{array}{rcrrcccccc}1 & 11000-10500 & 3.47 & 6.45 & 0.88 & 0.68 & 7.42 & 7.42 & 3.07 & 4.35 \\ 2 & 10500-10000 & 13.93 & 10.09 & 0.65 & 0.44 & 13.5 & 21.0 & 12.1 & 8.82 \\ 3 & 10000-9500 & 14.27 & 9.51 & 0.42 & 0.21 & 8.00 & 29.0 & 18.1 & 10.8 \\ 4 & 9500-9000 & 9.14 & 5.85 & 0.19 & -0.04 & 1.50 & 30.5 & 19.9 & 10.6 \\ 5 & 9000-8500 & 10.90 & 4.90 & -0.17 & -0.69 & -3.61 & 26.9 & \mathbf{1 8 . 0} & \mathbf{8 . 8 6} \\ 6 & 8500-8000 & 10.10 & - & -0.91 & - & -9.16 & 17.7 & 17.7 & 6.59 \\ 7 & 8000-7500 & 6.66 & - & -1.67 & - & -11.1 & 6.59 & (-0.04) \\ 8 & 7500-7000 & 2.73 & - & -2.43 & - & -6.64 & -0.04^{\dagger} & \end{array}$

*Values in bold-face type represent the ice flux immediately above the confluence of Wildhorse and Fall Creek Glaciers.

$\dagger$ Values represent a net imbalance of less than $1 \% .1$

ice thicknesses, which affects both velocities due to ice deformation and cross-sectional areas (Brugger, 1985). Sliding rates are more dependent on the total velocity $u$, and thus by Equation (4) the ice flux $Q$. Because of the non-uniqueness inherent in the reconstruction, it is possible to reduce sliding rates by reducing the accumulation values used for the particular specific net balance curve. However there is no paleoclimatic data to support such a reduction. Furthermore the sliding velocities, while high, are not unreasonable (Paterson, 1981, p. 71). Therefore the model II reconstruction represents a good "first-order" approximation of the glaciers and glacial systems as they are thought to have existed in Wildhorse Canyon during the late Pleistocene.

\section{CONGLUSIONS}

Till-provenance studies in Wildhorse Canyon provide additional constraints on the glaciological reconstructions of the late-Pleistocene paleoglaciers. When evaluated by established methods, reconstructions using one specific net balance curve for the entire glacier system appear quite reasonable in terms of the resulting ELAs. However, these reconstructions suggest that the ice fluxes contributed to the compound glacier from its two main tributaries were comparable in magnitude, contradicting the inferences drawn from the till-provenance data. A different approach to reconstruction accounted for possible variations in the specific net balance of the compound glacier suggested by the trend of cirque-floor elevations. This approach yields a glaciologically sound reconstruction of the glacial systems in Wildhorse Canyon that is consistent with the provenance data. Moreover, this more accurate reconstruction would not have been developed in the absence of the provenance data.

\section{ACKNOWLEDGEMENTS}

I am grateful to C. Jaworowski and an anonymous reviewer for their helpful comments on the original manuscript.

\section{REFERENCES}

Andrews, J. T. and G. H. Miller. 1972. Quaternary history of northern Cumberland Peninsula, Baffin Island, N.W.T., Canada: Part IV. Maps of the present glaciation limits and lowest equilibrium line altitude for northern and southern Baffin Island. Arct. Alp. Res., 4(1), $45-59$.

Brugger, K. A. 1985. Till provenance studies and glacier reconstructions in the Wildhorse Canyon area, Idaho. M.Sc. thesis, Lehigh University.)

Brugger, K.A.. R.A. Stewart and E. B. Evenson. 1983. A till provenance study and its implication for the style and chronology of glaciation of the Wildhorse Canyon area, Idaho. In Evenson, E. B., C. Schlüchter and J. Rabassa, eds. Tills and related deposits: genesis/ petrology/application/stratigraphy. Rotterdam, A. A. Balkema, 151-175.

Davis, J. C. 1986. Statistics and data analysis in geology. Second edition. New York, etc.. John Wiley and Sons.

Dover, J.H. 1981. Geology of the Boulder-Pioneer wilderness study arca, Blaine and Custer Counties, Idaho. U.S. Geol. Surv. Bull. 1475A.

Grosval'd, M. G. and V. M. Kotlyakov. 1969. Present-day glaciers in the U.S.S.R. and some data on their mass balance. J. Glaciol., 8 (52), $9-22$.

Hawkins, F. F. 1985. Equilibrium-line altitudes and paleoenvironment in the Merchants Bay area, Baffin Island, N.W.T., Canada. J. Glaciol., 31(109), 205-213.

Kuhn, M. 1981. Climate and glaciers. International Association of Hydrological Sciences Publication 131 (Symposium at Canberra 1979 - Sea Level. Ice and Climatic Change), 3-20.

Kuhn, M. 1984. Mass budget imbalances as criterion for a climatic classification of glaciers. Geogr. Ann., 66A (3), 229-238.

Leonard, E. M. 1984. Late Pleistocene equilibrium-line altitudes and modern snow accumulation patterns, San Juan Mountains, Colorado, U.S.A. Arct. Alp. Res., $16(1), 65-76$.

Leonard, E. M. 1989. Climatic change in the Colorado Rocky Mountains: estimates based on modern climate at Late Pleistocene equilibrium-lines. Arct. Alp. Res., 21 (3), 245- 255.

Locke. W. W. 1990. Late Pleistocene glaciers and climate of western 
Montana, U.S.A. Arct. Alp. Res., 22(1), 1 - 13.

Meier, M.F. and A.S. Post. 1962. Recent variations in mass net budgets of glaciers in western North America. International Association of Scientific Hydrology Publication 58 Symposium at Obergurgl 1962 Variations of Glaciers), $63-77$.

Meier, M. F., W. V. Tangborn. L. R. Mayo and A. Post. 1971. Combined ice and water balances of Gulkana and Wolverine Glaciers, Alaska, and South Cascade Glacier, Washington. 1965 and 1966 water years. U.S. Geol, Surv. Prof. Pap. 715-A.

Meierding, T.C. 1982. Late Pleistocene glacial equilibrium-line altitudes in the Colorado Front Range: a comparison of methods. Quat. Res., 18 3), 289-310.

Murray, D.R. and W. W. Locke, III. 1989. Dynamics of the Late Pleistocene Big Timber Glacier, Crazy Mountains, Montana, U.S.A. J. Glaciol., $35(120), 183-190$.

Nye, J. F. 1965. The flow of a glacier in a channel of rectangular, elliptic or parabolic cross-section. J. Glaciol., 5 41), 661-690.

Paterson, W.S. B. 1981. The physics of glaciers. Second edition. Oxford, etc., Pergamon Press.

Pierce, K. L. 1979. History and dynamics of glaciation in the northern Yellowstone National Park area. C.S. Geol. Surv. Prof. Pap. 729-F.

Porter, S. C. 1964. Composite Pleistocene snow line of Olympic Mountains and Cascade Range, Washington. Geol. Soc. Am. Bull.. 75 (5), $477-482$.

Porter, S. C. 1975. Equilibrium-line altitudes of Late Quaternary glaciers in the Southern Alps, New Zealand. Quat. Res., 5 1), $27-47$.

Porter, S. C. 1977. Present and past glaciation threshold in the Cascade Rangc, Washington. U.S.A.: topographic and climatic controls and paleoclimatic implications. J. Glaciol., 18 78), 101-116.
Porter, S. C. 1981. Glaciological evidence of Holocene climatic change. In Wigley, T.M. L.. M.J. Ingram and G. Farmer, eds. Climate and history: studies of past climates and their impact on man. Cambridge. Cambridge University Press, 82-110.

Porter, S. C., K. L. Pierce and T.D. Hamilton, 1983. Late Wisconsin mountain glaciation in the western United States. In Wright, H. E.. Jr, ed. Lale-Quaternary emironments of the Lniled States. Vol. I. Minneapolis, MN, University of Minnesota Press, 71-111.

Seltzer, G. O. 1994. Climatic interpretation of alpine snowline variations on millennial time scales. Quat. Res., 412 2) 154159.

Torsnes, I., N. Rye and A. Nesje. 1993. Modern and Little Ice Age equilibrium-line altitudes on outlet valley glaciers from Jostedalsbreen, western Norway: an evaluation of different approaches to their calculation. Arct. Alp. Res., 25 2), 106-116.

Wendler, G., C. Fahl and S. Corbin. 1975. Mass balance studies on McCall Glacier, Brooks Range, Alaska. Intematimal Association of Hydrological Sciences Publication 104 Symposium at Moscow 1971 Snow and lee in Mountainous Areas), 197-201.

Young, G.J. and A. D. Stanley. 1976a. Canadian glaciers in the International Hydrological Decade program, 1965-1974. No. 3. Ram River Glacier, Alberta summary of measurements. Ottawa, Inland Waters Directorate, Water Resources Branch. Scientific Series 70.

Young, G.J. and A. D. Stanley. 1976b. Canadian glaciers in the International Hydrological Decade program. 1965-1974. No. 4. Peyto Glacier. Albertasummary of measurements. Ottawa, Inland Waters Directorate, Water Resources Branch. Scientific Series 71.

Zwick, T. T. 1980. A comparison between the modern and composite Pleistocene snow-lines, Absaroka and Beartooth Mountains, Montana-Wyoming, U.S.A. J. Glaciol., 25 92, 347-352. 